\title{
What Happens Now?
}

Julia Koehler MD

As someone who in the mid-to the late 2000s - the George W. Bush administration - began trying to grasp the vast, incomprehensible cruelties inflicted on our immigrant patient families, neighbors, and community members, I am trying to think about what happens now?

The Biden tickets' victory (where on Saturday I just felt pure ecstasy) is now causing me flashbacks to the Obama administration's brutality against immigrants. While not engaging in publicly advertised performances of cruelty, like taking children away from parents at the border, so over 500 children now may never know where their parents are, the Obama administration inflicted indelible harm on immigrant children and families.

The Obama administration deported more immigrants than all previous presidential administrations combined: over 2.5 million. It is estimated that for every two deported adults, a child is left behind. Thus, the Obama administration left over a million children, plus some hundreds of thousands, as deportation orphans. I know some of them. This trauma cannot be recovered from for the rest of these children's' lives. (https://abcnews.go.com/Politics/ obamas-deportation-policy-numbers/story?id=41715661)

\section{"The Obama administration deported more immigrants than all previous presidential administrations combined: over $\mathbf{2 . 5}$ million. It is estimated that for every two deported adults, a child is left behind. Thus, the Obama administration left over a million children, plus some hundreds of thousands, as deportation orphans. I know some of them."}

The Obama administration claimed they were deporting "felons, not families." My anecdotal experience, and knowledge of community organizations, shows that this was completely untrue. Nevertheless, that slogan of "felons, not families" has a more sinister back story. In 1996, President Clinton signed the Orwellian-named "Illegal Immigration Reform and Immigrant Responsibility Act" (https://www.vox.com/2016/4/28/11515132/iirira-clinton-immigration and https://immigrantjustice.org/staff/blog/why-we-must-abolish-1996-law-has-destroyed-thousands-families-video), which turned "returning" to this country after deportation into a felony.

One of my patient's father had done this. He was then imprisoned for $11 / 2$ years in Georgia before being deported again to the Dominican Republic. This little boy was devastatingly traumatized by his father's imprisonment and then his loss. Seeing this little boy in front of me is one reason I can never stop talking about this. Of course, his father had come back after being deported the first time: the reason he came to this country the first time, inability to provide for his family in the DR, had not improved. And his family was now in Massachusetts.

Under the Obama administration, illegal entry after deportation became by far the most frequently prosecuted federal felony; see, for example, https://trac.syr.edu/immigration/reports/251/. In other words, they were turning families into felons. That is behind the Obama administration's statistics of having deported criminals.

Under the Obama administration, in a bill passed in 2009 while Democrats had House and Senate majorities, ICE was mandated to hold 34,000 immigrants in detention every night. I.e., the number of people imprisoned by ICE was mandated by Congress. See https://www.npr.org/2013/11/19/245968601/little-known-immigration-mandate-keeps-detention-beds-full and details https://immigrantjustice.org/sites/default/files/contenttype/issue/documents/2017-01/Immigration\%20Detention\%20 Bed\%20Quota\%20Timeline\%202017 01 05.pdf). The vast immigrant imprisonment Gulag in which people are now dying of COVID-19 was built out at that time and handed over intact to the Trump administration. Of note, the 2017 appropriations bill eliminated this quota, but detentions continued.

The involvement of for-profit corporations in immigration enforcement was further expanded in the first years of the Obama administration over what the GW Bush administration had done. "As of August 2016, nearly three-quarters of the average daily immigration detainee population was held in facilities operated by private prison companies." From https://www.migrationpolicy.org/article/ profiting-enforcement-role-private-prisons-us-immigration-deten-

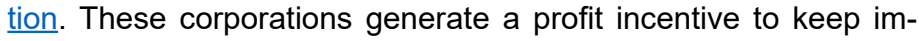
prisoning immigrants. Under the Obama administration, "Between 2007 and 2014, CoreCivic's overall annual profits grew from about $\$ 133$ million to $\$ 195$ million, and GEO Group's profits grew from about $\$ 42$ million to $\$ 144$ million yearly" (from the same source).

\section{"The involvement of for-profit corporations in immigration enforcement was further expanded in the first years of the Obama administration over what the GW Bush administration had done. 'As of August 2016, nearly three-quarters of the average daily immigration detainee population was held in facilities operated by private prison companies."}

It was the Obama administration that built a giant holding center 
for children that had crossed the border - see, for example, https:// www.valleycentral.com/news/local-news/new-mcallen-facility-tohouse-1000-immigrant-children/ - and it was the Obama administration that built the cages into which Donald Trump's administration put the children they took from their parents, see https:// azcapitoltimes.com/files/2014/06/24-guatemala-nogales-full.png, which shows Obama Homeland Security Secretary Jeh Johnson touring a facility for children in Arizona in 2014, together with Arizona Gov. Jan Brewer

And perhaps more fundamental than any of this, the Obama administration contributed to the violent taking of labor and land from people in Honduras and Guatemala, accelerating the reasons families flee to this country by tacitly supporting the 2009 military coup in Honduras that deposed the president who wanted to raise the minimum wage (see https://www.washingtonpost.com/blogs/postpartisan/wp/2016/04/19/hillary-clintons-dodgy-answers-on-honduras-coup/ and https://www.theguardian.com/world/2016/aug/31/ hillary-clinton-honduras-violence-manuel-zelaya-berta-caceres).

The Obama administration let the sequelae of the $1954 \mathrm{ClA}$ backed coup in Guatemala (https://www.bbc.com/news/av/stories-48638209 and https://www.umbc.edu/che/tahlessons/pdf/ historylabs/Guatemalan Coup student:RS01.pdf ) and the 1980s genocidal wars against indigenous Guatemalans play themselves out undisturbed while deporting innumerable people back to Guatemala (see for example https://www.nytimes.com/2014/05/15/ opinion/new-bad-old-times-for-guatemala.html).

Having seen the heartbreaking stunting of Guatemalan children in indigenous towns, and heard from parents there, that there is no way they can get more food for their children, the callousness with which the fathers of these children are treated as felons when they return to this country after deportation, is gut-wrenching.

In 2015, Vice President Biden did not play a good role in response to the tens of thousands of youth and children fleeing to this country unaccompanied in 2014 and 2015: https://nacla.org/ news/2015/02/27/will-biden\%27s-billion-dollar-plan-help-centralamerica

Among the immigrant families I know, a large majority would have wanted to stay home if they could have had a sustainable life and safety there. Over the decades, our own governments' policies support the rapaciousness of US agricultural and mining corporations, who have taken this option away from them. I believe that continuing to prefer oblivion to these policies, over the active opposition to them is the biggest disservice we can do our immigrant families.

We need to think now about what we need to ask of the Biden administration, other than revoking Donald Trump's executive orders and regulation changes like "Public Charge." My top 1, 2, and 3 are repeal IIRAIRA (Illegal Immigration Reform and Immigrant Responsibility Act of 1996). That law is like the Clinton administration's Crime Bill (and passed around the same time), which laid the foundation for mass incarceration and the New Jim Crow.

I also think we need to repeal NAFTA (https://www.nytimes.com/ roomfordebate/2013/11/24/what-weve-learned-from-nafta/undernafta-mexico-suffered-and-the-united-states-felt-its-pain and https://cronkitenews.azpbs.org/buffett/mexico/corn/) and CAFTA (https://www.citizen.org/article/central-america-free-trade-agreement-cafta/), so people regain the right to stay at home. This repeal would be good for many people in this country too (https://www.epi. org/blog/naftas-impact-workers/). However, those in favor of these treaties are vastly more powerful than those against them. I also realize President-elect Biden is a co-architect of these measures.

"We need to think now about what we need to ask of the Biden administration, other than revoking Donald Trump's executive orders and regulation changes like "Public Charge." "'

I was so happy on Saturday morning. But I think we now have our work cut out for us. Clarity may be an important place to start.

\section{References:}

1. https://abcnews.go.com/Politics/obamas-deportation-policynumbers/story?id $=41715661$

2. https://www.vox.com/2016/4/28/11515132/iirira-clinton-immigration

3. https://immigrantjustice.org/staff/blog/why-we-must-abolish1996-law-has-destroyed-thousands-families-video

4. https://trac.syr.edu/immigration/reports/251/

5. https://www.npr.org/2013/11/19/245968601/little-known-immigration-mandate-keeps-detention-beds-full

6. https://immigrantjustice.org/sites/default/files/content-type/ issue/documents/2017-01/Immigration $\% 20$ Detention $\% 20$ Bed\%20Quota\%20Timeline\%202017 01 05.pdf

7. https://www.migrationpolicy.org/article/profiting-enforcement-role-private-prisons-us-immigration-detention

8. https://www.valleycentral.com/news/local-news/new-mcallen-facility-to-house-1000-immigrant-children/

9. https://azcapitoltimes.com/files/2014/06/24-quatemala-nogales-full.png

10. https://www.washingtonpost.com/blogs/post-partisan/ wp/2016/04/19/hillary-clintons-dodgy-answers-on-honduras-coup/

11. https://www.theguardian.com/world/2016/aug/31/hillary-clinton-honduras-violence-manuel-zelaya-berta-caceres

12. https://www.bbc.com/news/av/stories-48638209

13. https://www.umbc.edu/che/tahlessons/pdf/historylabs/Guatemalan Coup student:RS01.pdf

14. https://www.nytimes.com/2014/05/15/opinion/new-bad-oldtimes-for-guatemala.html

15. https://nacla.org/news/2015/02/27/will-biden\%27s-billiondollar-plan-help-central-america

16. https://www.nytimes.com/roomfordebate/2013/11/24/whatweve-learned-from-nafta/under-nafta-mexico-suffered-andthe-united-states-felt-its-pain

17. https://cronkitenews.azpbs.org/buffett/mexico/corn/

18. https://www.citizen.org/article/central-america-free-tradeagreement-caftal

19. https://www.epi.org//blog/naftas-impact-workers

The author has no conflicts to disclose NT 

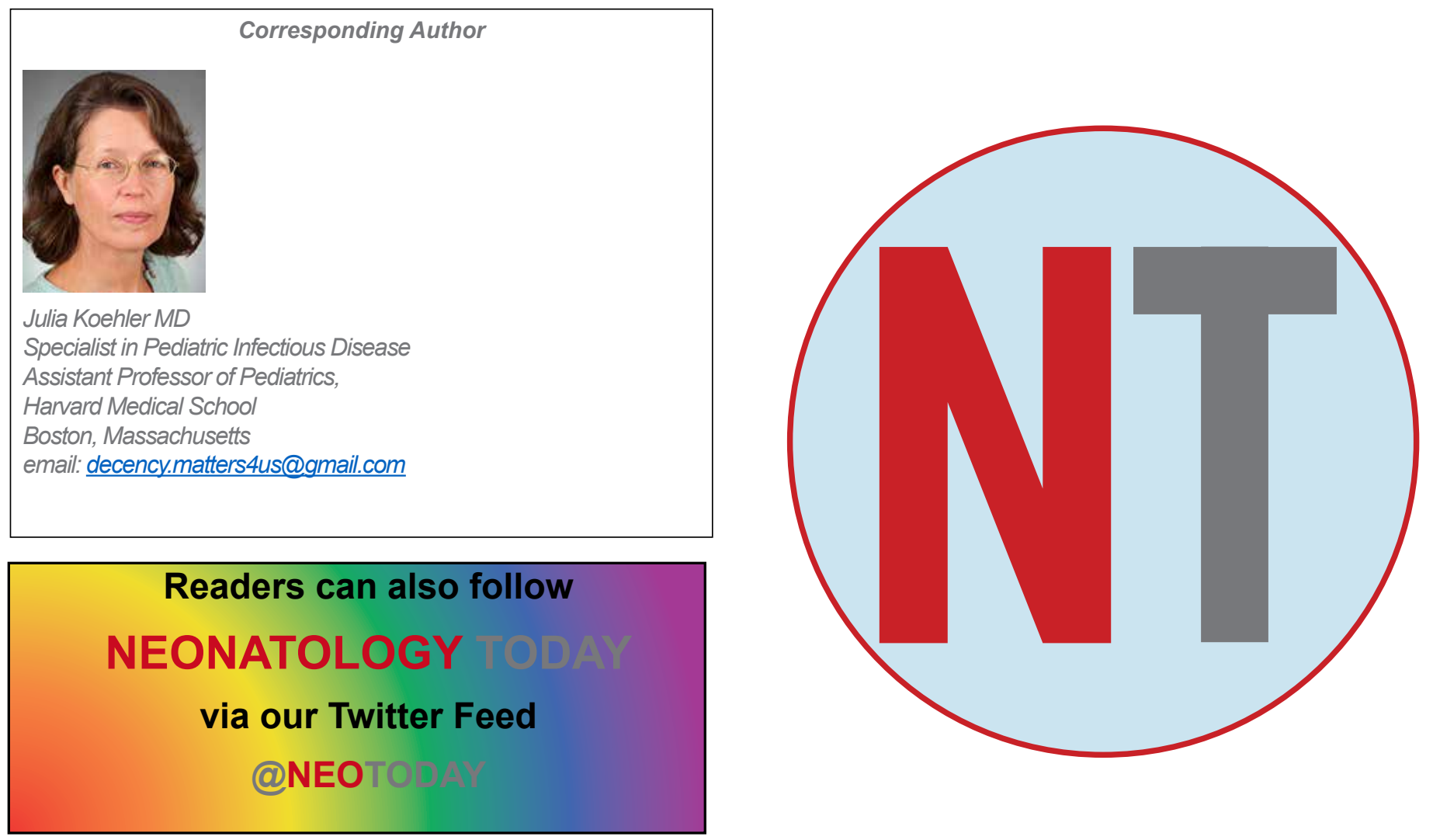

Education that is...

- Story-Driven

- Trauma-Informed

- Evidence-Based

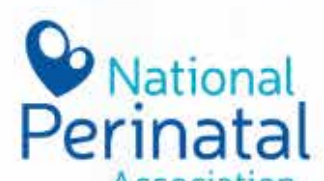
Association

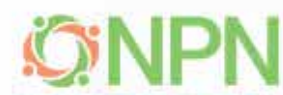
NICU PAFENT NETWORK

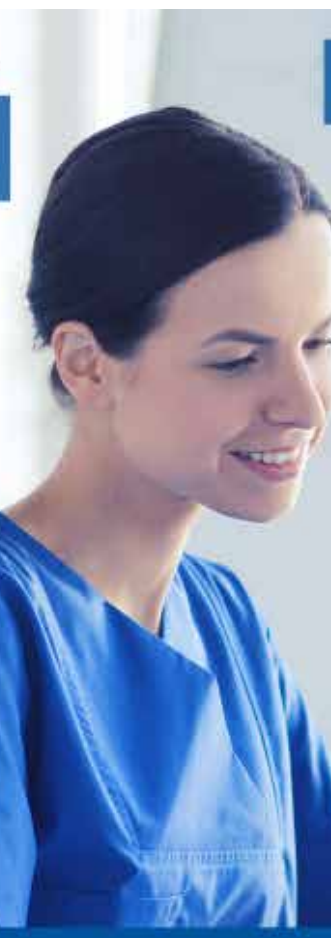

\section{Visit us at www.mynicunetwork.org}

The preeminent provider of compelling perinatal education on

psychosocial support created through interprofessional collaboration

Take our "Coping with COVID-19" program for FREE 